\title{
Comparative transcriptome analysis within the Lolium/Festuca species complex reveals high sequence conservation
}

\author{
Adrian Czaban ${ }^{1}$ Sapna Sharma² , Stephen L Byrne ${ }^{1}$, Manuel Spannagl ${ }^{2}$, Klaus FX Mayer ${ }^{2}$ and Torben Asp ${ }^{*^{*}}$
}

\begin{abstract}
Background: The Lolium-Festuca complex incorporates species from the Lolium genera and the broad leaf fescues, both belonging to the subfamily Pooideae. This subfamily also includes wheat, barley, oat and rye, making it extremely important to world agriculture. Species within the Lolium-Festuca complex show very diverse phenotypes, and many of them are related to agronomically important traits. Analysis of sequenced transcriptomes of these non-model species may shed light on the molecular mechanisms underlying this phenotypic diversity.

Results: We have generated de novo transcriptome assemblies for four species from the Lolium-Festuca complex, ranging from 52,166 to 72,133 transcripts per assembly. We have also predicted a set of proteins and validated it with a high-confidence protein database from three closely related species (H. vulgare, B. distachyon and O. sativa). We have obtained gene family clusters for the four species using OrthoMCL and analyzed their inferred phylogenetic relationships. Our results indicate that VRN2 is a candidate gene for differentiating vernalization and non-vernalization types in the Lolium-Festuca complex. Grouping of the gene families based on their BLAST identity enabled us to divide ortholog groups into those that are very conserved and those that are more evolutionarily relaxed. The ratio of the non-synonumous to synonymous substitutions enabled us to pinpoint protein sequences evolving in response to positive selection. These proteins may explain some of the differences between the more stress tolerant Festuca, and the less stress tolerant Lolium species.

Conclusions: Our data presents a comprehensive transcriptome sequence comparison between species from the Lolium-Festuca complex, with the identification of potential candidate genes underlying some important phenotypical differences within the complex (such as VRN2). The orthologous genes between the species have a very high \%id $(91,61 \%)$ and the majority of gene families were shared for all of them. It is likely that the knowledge of the genomes will be largely transferable between species within the complex.
\end{abstract}

Keywords: Lolium-Festuca complex, RNAseq, Comparative transcriptomics, Gene families

\section{Background}

Next Generation Sequencing is a valuable tool for the analysis and study of transcriptomes of non model species [1], especially when resources are limited and a complete re-sequencing of the genome is not practical. Transcriptome sequencing allows us to overcome some of the challenges associated with sequencing complex, highly repetitive and large plant genomes.

\footnotetext{
*Correspondence: Torben.Asp@mbg.au.dk

1 Department of Molecular Biology and Genetics, Aarhus University, Forsøgsvej 1, 4200 Slagelse, Denmark

Full list of author information is available at the end of the article
}

The Lolium-Festuca complex is a common name for the grasses belonging to both the Lolium genus and broad leaved fescues from the Schedonorus subgenus of Festuca. Both genus are part of the Poaceae family [2], but their exact taxonomic relationship is unclear, with reports of a shared common ancestor [3,4] or the Lolium diverging from Festuca around 2 million years ago [5]. The Poaceae family also includes species such as wheat, barley, bamboo, rice, sorghum and sugarcane making it one of the most important plant families from an agricultural, economic and ecological point of view [6]. The Lolium genus contains ten species [7] all of which are exclusively diploid 
in nature [8], whereas the Festuca genus comprises 600 species and the ploidy numbers range from diploid up to dodecaploid [9]. The species belonging to the LoliumFestuca complex are thought to be closely related and interspecific crosses between some of them occur naturally in the wild. In fact, Festuloliums, which are a cross between Loliums and Fescues are very well established as agriculturally important plants [10-12]. This has led to many discussions as to the exact taxonomy of the complex, as one can find over 500 names for the few Lolium species [13]. However, despite such a close relationship and being universally distributed around the globe, the plants within the complex exhibit significant diversity for agriculturally important traits [14] such as growth speed, root length, forage quality, resistance to biotic and abiotic stresses, annuality and perenniality. The Lolium species generally have a good nutrient content and are highly palatable [15]. L.perenne can withstand heavy grazing, and L. multiflorum is characterized by rapid establishment [16]. All these traits make them a very good choice for animal fodder. On the other hand, F. pratensis exhibits higher persistence, with a better developed root system allowing it to grow on lower quality soils. It also exhibits resistance to extreme abiotic conditions, such as drought and cold stress, being found as far north as within the Arctic Circle. Introgression of specific traits within the complex are possible and natural hydrids can be found in north-western Europe [17].

Numerous studies have succesfully introduced important traits from F. pratensis into Loliums, including crown rust resistance in L. perenne [18] and L. multiflorum [19-21], freezing tolerance [22] and drought tolerance in L. multiflorum [23]. Species from the Lolium-Festuca complex provide a large pool of genetic variation, both within single species, as well as within the complex. This makes it possible to breed forage and turf vartieties suited for use under a range of environments. Not suprisingly, Poacea, to which both Festuca and Lolium belong has been proposed as a model clade for comparative genomics [24]. Currently well-annotated genomes for this clade are Brachypodium distachyon [25], and Oryza sativa [26] with ongoing research into Hordeum vulgare [27].

The aims of the study were to; (1) reconstruct the transcriptomes of four species within the LoliumFestuca complex: F. pratensis, L. multiforum, L. m. westerwoldicum and L. temulentum. This would complement the already published Lolium perenne transcriptome $[28,29],(2)$ establish the phylogeny of the species based on orthologous protein sequences, (3) identify and compare gene families across the analyzed transcriptomes, and (4) identify genes under positive selection between the very resistant to biotic and abiotic stresses F. pratensis, and more susceptible Lolium species.

\section{Results and discussion \\ De-novo assembly of transcriptomes from the \\ Lolium-Festuca complex}

We focused on generating transcriptome assemblies for four species within the Lolium-Festuca complex. Reads were error-corrected using ALLPATHS-LG tool [30], and assembled using Trinity software [31] to produce transcriptome assemblies that varied in transcript number between 52,166 and 72,133 after quality filtering for lowread support transcripts (Table 1). The distribution of transcript length is very similar between the four species (Figure 1), and in all cases a large portion of the assembly is contained within transcripts that are over $1000 \mathrm{bp}$ in length. We have taken several approaches to evaluate the quality of each assembly and determine how comparable the four assemblies are. First, we identified which transcripts from three closely related species (B.distachyon, $O$. sativa and $T$. aestivum) share the greatest sequence similiarity with transcripts from the four Lolium-Festuca complex species. We then determined how much overlap there was between the transcript from our de-novo assemblies and the transcript from the related species. A high proportion of the transcripts can be aligned fully (100\%) or almost fully $(80 \%)$ to the transcripts from the related species (Table 2). The highest number of hits were found to the wheat gene set, the closest relative in this comparison. Secondly, we used the CEGMA pipeline [32] to evaluate the completeness of our assemblies. This is a tool that assesses the presence and coverage of a set of 248 extremely conserved core eukaryotic genes (CEGs). The tool is routinely used for evaluating genomic assemblies, however, it has also been used for evaluating transcriptome assemblies $[33,34]$. The percentage of complete CEGs ranged from 88.71 to 95.56 , and the percentage of partially complete CEGs ranged from 94.76 to 97.58 (Table 3). The average number of orthologs per CEG and

Table 1 Statistics of the filtered de-novo assemblies

\begin{tabular}{|c|c|c|c|c|c|}
\hline Species & Number of sequences & Total nucleotide count & Max. transcript length & Average transcript length & N50 \\
\hline F.pratensis & 72,133 & $81,313,606$ & 15,432 & 1,127 & 1,791 \\
\hline L. multiflorum & 55,570 & $58,246,475$ & 15,160 & 1,048 & 1,646 \\
\hline L.m.westerwoldicum & 52,166 & $55,142,140$ & 15,224 & 1,057 & 1,651 \\
\hline L. temulentum & 59,309 & $67,863,492$ & 15,295 & 1,144 & 1,802 \\
\hline
\end{tabular}




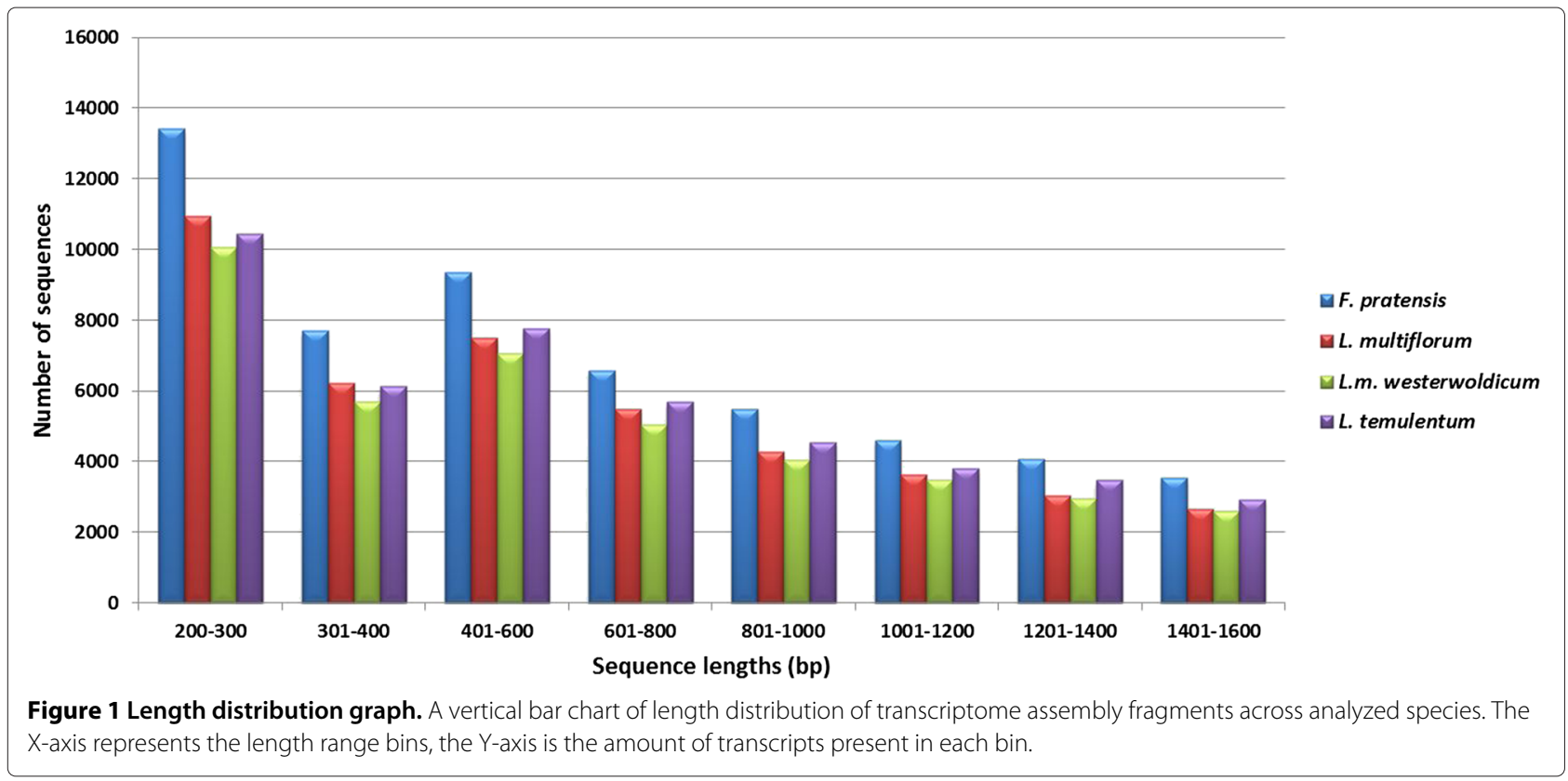

the \% of detected CEGs that had more than 1 ortholog were similar across the four species. Our results point to transcriptome assemblies that reflect a representative portion of the transcriptome complexity, and are comparable between the four species.

We predicted protein coding sequences from our transcriptome assemblies using Transdecoder [31], and the numbers of predicted proteins ranged between 30,182 and 39,981. We then looked at the percentage of proteins predicted from complete transcripts, that is having both the 3' and 5' UTRs present - their numbers ranged from 10,680 to 16,850 . Pfam domains have been assigned for between 54.82 and $60.23 \%$ of the proteins for each species. Around $4 \%$ of the proteins were predicted to have signal peptides and around 15\% to have transmembrane helices. The number of transcripts with $\mathrm{GO}$ terms assignment was between $54.8-60.8 \%$ (Table 4). A functional annotation report for each species is provided in Additional file 1: Table S1, Additional file 2: Table S2, Additional file 3: Table S3 and Additional file 4: Table S4.

\section{Comparative gene family analysis}

One way of understanding differences between related species on a genome-wide scale is to compare and find contrasts in the entire gene complement of each species. Best reciprocal BLAST hits between genes within a single species suggests the genes are paralogs. Best reciprocal BLAST hits between genes from different species suggests

Table 2 Full length transcripts analysis

\begin{tabular}{|c|c|c|c|c|}
\hline Species & Template protein dataset & $100 \%$ coverage & $>80 \%$ coverage & $>20 \%$ coverage \\
\hline & Wheat & 9,356 & 13,681 & 21,918 \\
\hline \multirow[t]{3}{*}{ F.pratensis } & Brachypodium & 7,488 & 10,430 & 15,350 \\
\hline & Rice & 6,355 & 9,391 & 13,360 \\
\hline & Wheat & 8,320 & 12,016 & 19,749 \\
\hline \multirow[t]{3}{*}{ L.multiflorum } & Brachypodium & 6,966 & 9,646 & 14,250 \\
\hline & Rice & 5,895 & 8,657 & 12,518 \\
\hline & Wheat & 8,352 & 12,088 & 19,615 \\
\hline \multirow[t]{3}{*}{ L.m. westerwoldicum } & Brachypodium & 7,028 & 9,695 & 14,276 \\
\hline & Rice & 5,905 & 8,720 & 12,495 \\
\hline & Wheat & 9,063 & 13,103 & 20,642 \\
\hline \multirow[t]{2}{*}{ L. temulentum } & Brachypodium & 7,543 & 10,481 & 15,118 \\
\hline & Rice & 6,328 & 9,368 & 13,154 \\
\hline
\end{tabular}


Table 3 Results of CEGMA analysis

\begin{tabular}{lcccc}
\hline Out of $\mathbf{2 4 8}$ & F. pratensis & L. multiflorum & L.m. westerwoldicum & L. temulentum \\
\hline \% of fully represented & 95.56 & 91.53 & 88.71 & 92.74 \\
\% of at least partially represented & 97.58 & 95.56 & 94.76 & 97.58 \\
average number of orthologs per CEG & 2.56 & 2.56 & 2.37 & 2.4 \\
\% of detected CEGs with more than 1 ortholog & 65.82 & 70.48 & 67.27 & 65.22 \\
\hline
\end{tabular}

the genes are orthologs, and this strategy is widely used to generate orthologous pairs [35]. We used OrthoMCL [36] in order to compute orthologous clusters for all of our predicted proteins from the four species. We filtered proteins for the longest peptide predicted from a single representative transcript per locus, in order to avoid bias in the creation of the orthologous groups. We generated 15,930 clusters, assigning $57,822(76,59 \%)$ to clusters of sizes from 2 to 176 proteins. The number of proteins contained in all clusters for each species varied between 14,161 and 14,835 .

Most of the proteins are found in clusters containing genes from at least two species, with 8,644 gene families shared between all four species (Figure 2). The number of unique (species-specific) clusters is relatively low, which is not surprising considering that the analyzed species are seperated by very small evolutionary distances. $L$. multiflorum and $L$. $m$. westerwoldicum have the smallest number of species - specific proteins, and many protein sequences that are shared only between these two. Again, this is not surprising because $L$. $m$. westerwoldicum is a 'species' derived from L. multiflorum through selective breeding for annuality [37]. Out of the gene families identified as unique, two predicted proteins from $F$. pratensis are showing high sequence identity with a ZCCT2-A2 VRN2 homologue from T. urartu [B8X8J1]. VRN2 has an important role in the vernalization/flowering pathway, by preventing the flowering of the plant unless it has experienced a period of cold temperatures and/or short days [38]. If there is a cold period, VRN2 becomes downregulated and allows the expression of the FT1 gene, which promotes flowering $[39,40]$. F. pratensis is a perennial species with predominantly a strong vernalization requirement [41]. All of the other species analyzed are of bi-annual or annual type and have a facultative ( $L$. multiflorum) or no vernalization requirement ( $L$. m. westerwoldicum and L. temulentum [42]). Samples for RNA-seq were taken from non vernalised plants, and it is therefore not surprising that VRN2 has been identified in the transcrtipome assembly of $F$. pratensis. The Lolium species without a vernalisation requirement do not have the VRN2 transcript present in their assemblies. A blastp alignment of the identified Festuca protein against the other transcriptomes revealed no significant hits. None of the original reads from the other species align back to the predicted VRN2 transcript, confiming that the VRN2 transcript is not present in the RNA-seq data sets of nonperennial species. We know from other studies that VRN2 is expressed in a $L$. perenne which does have a strong vernalization requirement [43]. The absence of VRN2 expression has been proven to enable FT induction and flowering in the closely related cereals $[44,45]$. Loss of function of VRN2 in wheat results in plants that do not require vernalization to flower, and it is the genetic locus responsible for distinguishing spring and winter wheat types [46]. Our results suggest that VRN2 is a key gene for differentiating vernalisation and non-vernalisation requiring species withinin the Lolium-Festuca complex. Other proteins identified as being species-unique included disease resistance proteins for F. pratensis, $\mathrm{ABC}$ transporter C for L. multiflorum, part of a ubiquitin ligase complex for L. m. westerwoldicum and ubiquin for L. temulentum (Table 5).

\section{Analysis of clusters with high and low sequence similarity}

The average identity of sequences in the OrthoMCL groups indicates the level of similarity among proteins belonging to that group. The combined average sequence identity (referred to as \%id) of all protein families was 91.61\%. 747 families contained highly conserved proteins, and their \%id was equal to 100. 2,056 families have a \%id below $80 \%$, constituting less conserved groups. Using the DAVID database [47] we have analyzed which functional annotation terms are overrepresented in the groups with

Table 4 Overview of functional annotation output of the four species transcriptomes

\begin{tabular}{|c|c|c|c|c|c|c|}
\hline Species & Proteins predicted & Pfam & sprot & signalp & tmHMM & GO \\
\hline F.pratensis & 39,981 & 21,921 & 21,653 & 1,622 & 5,630 & 21,928 \\
\hline L. multiflorum & 30,940 & 18,464 & 18,386 & 1,400 & 4,609 & 18,569 \\
\hline L.m. westerwoldicum & 30,182 & 18,179 & 18,170 & 1,339 & 4,703 & 18,349 \\
\hline L.temulentum & 35,005 & 19,507 & 19,248 & 1,524 & 5,104 & 19,488 \\
\hline
\end{tabular}




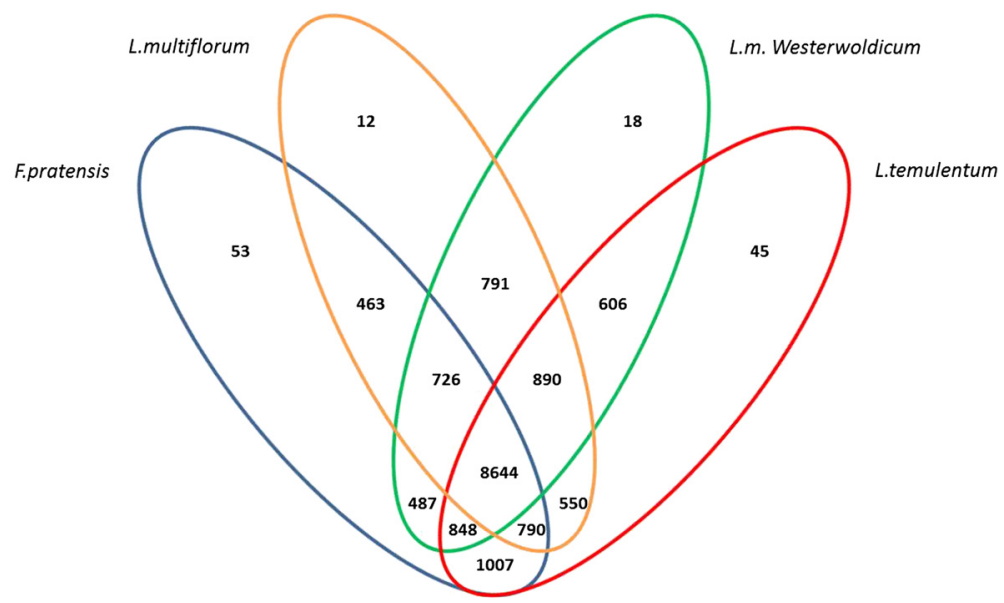

Figure 2 Orthologous groups distribution. The Venn diagram shows the distribution of shared and divergent orthologous groups from an OrthoMCL analysis of Lolium-Festuca complex proteomes, based on non-redundant dataset. The numbers in each division show the amount of groups for each combination.

different levels of percent sequence identity. GO Biological Process, INTERPROSCAN, and KEGG Pathway terms have been used for the annotation. Out of the proteins from groups having 100\% identity 513 sequences could be matched in the DAVID database. They have been grouped into 45 clusters enriched for GO Biological Process terms. The most abundant classes of enriched terms include

Table 5 Annotation of the species-unique proteins identified

\begin{tabular}{|c|c|}
\hline Species & Selected protein homologs \\
\hline & ZCCT2-A2 VRN2 homologue [T. urartu] \\
\hline & Serine/threonine-protein kinase SMG1 [A. tauschii] \\
\hline & serine/threonine-protein kinase GSO1 [A. tauschii] \\
\hline & Hydroxyisourate hydrolase [A. tauschii] \\
\hline & Disease resistance protein RPM1 [T. urartu] \\
\hline & Putative disease resistance protein RGA4 [T. urartu] \\
\hline & ABC transporter G family member 37 [T. urartu] \\
\hline \multirow[t]{2}{*}{ F. pratensis } & $60 S$ ribosomal protein L28-1 [A. tauschii] \\
\hline & Ribosomal L1 domain-containing protein 1 [T. urartu] \\
\hline \multirow[t]{6}{*}{ L. multiflorum } & ABC transporter C family member 3 [T. urartu] \\
\hline & Coatomer subunit beta'-2 [T. urartu] \\
\hline & Kinesin-like protein KIF15 [T. urartu] \\
\hline & Kinesin-like protein KIF15 [A. tauschii] \\
\hline & GRF zinc finger family protein [O. sativa Japonica Group] \\
\hline & DNA mismatch repair protein mutS [A. tauschii] \\
\hline \multirow[t]{7}{*}{ L.m. westerwoldicum } & Splicing factor 3 A subunit 3 [T. urartu] \\
\hline & DNA mismatch repair protein Mlh1 [A. tauschii] \\
\hline & ubiquitin [S. aucuparia] \\
\hline & calcineurin B-like protein 4 [T. aestivum] \\
\hline & fasciclin-like protein FLA14 [T aestivum] \\
\hline & anthranilate N-benzoyltransferase protein 1 [A. tauschii] \\
\hline & calcineurin B-like protein 4 [T. aestivum] \\
\hline L. temulentum & $\begin{array}{l}\text { cyclopropane-fatty-acyl-phospholipid synthase }[\text { I. urartu } \\
\text { B3 domain-containing protein [A tauschii] }\end{array}$ \\
\hline
\end{tabular}

response to abiotic stress, ubiquitination, phosphorus metabolism, electron transport chain, protein localization, response to organic and hormone stimulus, positive regulation of transcription, carbohydrate metabolism, cell cycle, and meiotic cell cycle. Enriched KEGG pathway terms included purine and pirimidyne metabolism, pyruvate metabolism, glycolisis/gluconeogenesis, carbon fixation, biosynthesis of plant hormones, terpenoids, steroids and alkaloids, and citrate cycle. Enriched INTERPRO domains were related to ubiquitin, protein kinases, GTPases, ATPases, EF hands, and DNA/RNA helicases. Genes responsible for terms like basic metabolic processes related to biosynthesis and degradation, transcriptional and translational activity, protein synthesis and destination and signal transduction are amongst the most conserved in plants [48]. The same is true for genes involved in basic cell cycle machinery [49].

The families with a low \%id represent proteins with less restrained sequence conservation, with possible multiple copies allowing for more relaxed selection. For the families having below $80 \%$ id we have identified 1,548 IDs using DAVID, which group into 90 clusters enriched for GO Biological Process terms. Clusters with the highest enrichment scores consisted of proteins related to phosphorylation, enzyme linked receptor protein signalling pathway, response to radiation, light and abiotic stimulus, protein ubiquitination, proteolysys and protein catabolic processes, response to organic and hormone stimuli, ion transport, root development, nucleotide metabolic processes and response to hormone stimulus. Three clusters were identified for enriched KEGG pathways, related to metabolism of methane, cyanoamino acid and glycine, serine and threonine, phenylopropandoid biosynthesis, and gluconeogenesis, biosynthesis of 
alkaloids and terpenoids. 64 clusters have been enriched for INTERPRO domains, with ten highest containing protein kinases, $\mathrm{ABC}$ transporters, ubiquitin, ATPases, zinc fingers, sulfphate ion transporters, DNA/RNA helicases, EF-hands, EGF-like domains, and PAS domains. Full overview of the GO Biological Process annotation is available in Additional file 5: Table S5 and Additional file 6: Table S6.

\section{Phylogenetic analysis based on orthologous gene families}

The exact taxonomy of the Lolium-Festuca complex species is complicated and historically not completely agreed upon, with questions raised about the relationship between different Loliums as well as the origin of the species. The genus Festuca is considered to be ancestral to the genus Lolium, as it incorporates far more species and contains natural polyploids $[4,13,50]$. Evidence exists for both (i) the evolution of Loliums from a perennial Festuca subgenus Schedonorus ancestor [51], and (ii) a common ancestral form for both Lolium and Festuca $[3,4]$. Some reports are in favor of classifying the genus Lolium as part of the Schedonorus [52,53]. In general, the Lolium genus can be separated based on self-pollinating or out-pollinating behaviour. The most recent and complete analyses of the Lolium-Festuca complex reports the crown age of the Lolium - Festuca complex to be 8.97 +$1.5 \mathrm{Ma}$. It also reports the F. pratensis to have originated in the Southwest Asia around 2 million years ago, and the Loliums to have first diversified in the eastern Mediterranean region around 4.1 Ma [54].

In our study we performed the phylogenetic analysis using the orthologous groups identified by OrthoMCL. The clustering output was further filtered for conserved orthologous genes as a representative from each species that is, having exactly one representative in the cluster for each of the species. 4022 groups fulfilled this criteria. Using these groups we inferred gene trees (using PAML tool) which were then clustered using the Phylip tool to infer a consensus tree (Figure 3). It is important to note that gene trees were calculated based solely on the gene-coding regions obtained from assembled transcriptome sequences only. The numbers on the branches indicate the number of times the species are partitioned into the two sets (out of 4022 groups). This means, that the branch topology has the highest support, or has been represented most commonly in the input trees. However, we find that a high proportion of the original trees have a different topology. This points to a different phylogenetic relationship depending on the group of orthologous proteins analyzed. These findings make sense in light of the fact that some of the species in the complex are interfertile. The fact that introgression of genes is possible within the complex has been utilized in breeding efforts as well as in research [55-57]. The genomes of modern grass species are a result of more complex evolutionary mechanisms, and reticulate evolution in the complex has been previously proposed [58]. The consensus tree (phylogeny) strongly corresponds to the possible phylogeny of the Poaceae family reported in [54].

\section{Genes under positive selection pressure in Lolium species compared to $F$. pratensis}

We can identify two types of changes in the coding sequences - non synonymous ( $\mathrm{dN}$ ) substitutions, leading to change in the amino acid sequence, and synonymous (dS) substitutions, which are neutral for the amino acid sequence. The ratio of non-synonymous substitution rate (Ka) and synonymous substitution rate (Ks) is a parameter widely used to assess whether there is any directional selection acting on a protein coding gene. A ratio $<1$

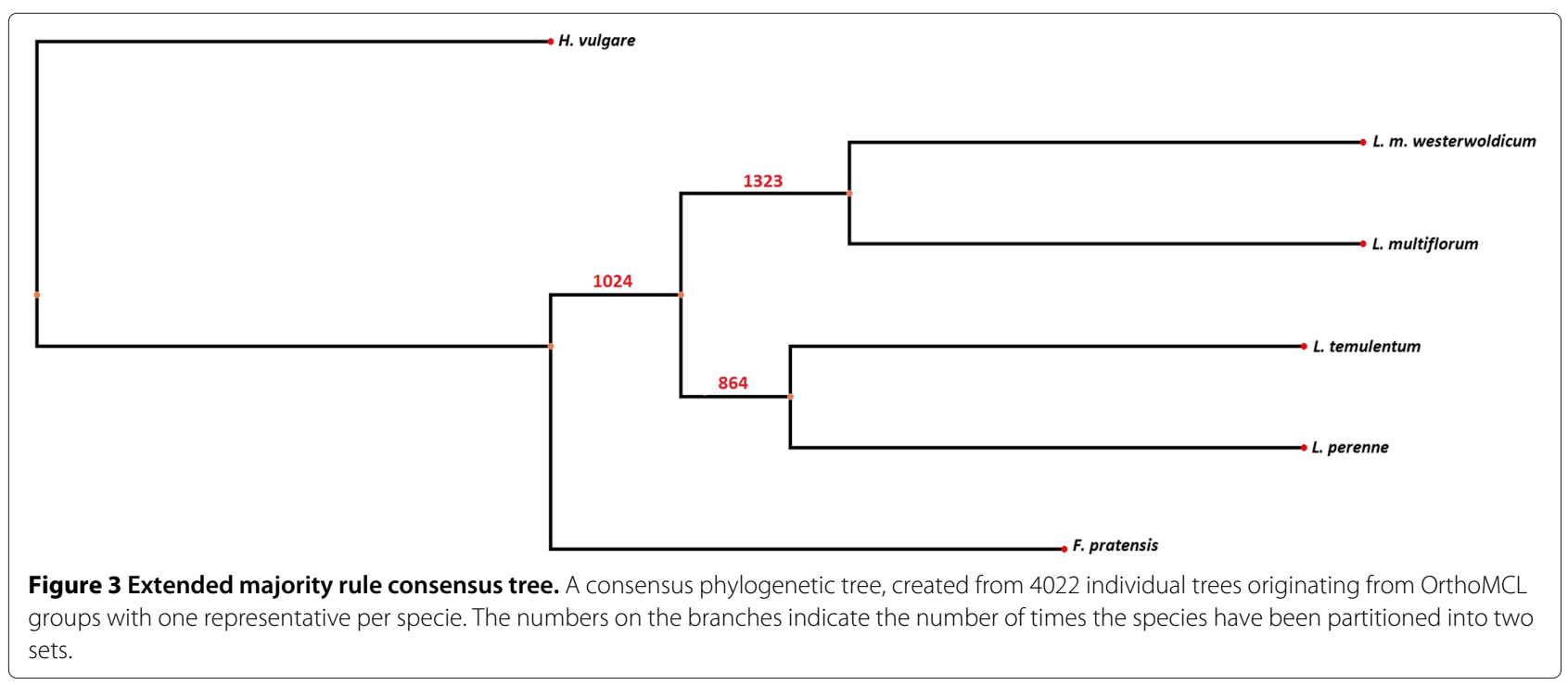


indicates that the protein is under purifying selection, whereas a ratio of $>1$ is a good indication of positive selection pressure $[59,60]$. In such a closely related clade, only a small amount of genes can be expected to be responsible for phenotypical differences [61]. We undertook pairwise comparison of transcriptome datasets. Putative orthologous genes have been then classified according to the best bi-directional blast criteria (see Methods), and for every comparison we selected transcript pairs with a $\mathrm{Ka} / \mathrm{Ks}$ ratio above 1 . We have focused on comparing the F. pratensis with the other analyzed species, as it has various features that are important from an agricultural perspective, which include superior biotic and abiotic stress tolerance, good persistency and perenniality. The sequence identity distribution is very uniform among the pairwise comparison, with it's peak around 95\% (Figure 4). We focused our analysis towards genes involved in stress resistance, cell cycle and development related proteins, with the most relevant ones identified listed for every comparison. The overall distribution of $\mathrm{Ka} / \mathrm{Ks}$ ratio of all pairwise comparisons is very similar, with almost every pair of proteins showing signs of purifying selection (Figure 5). The median ratio was very consistent, between 0.1741 for $L$. multiflorum and 0.1883 for $L$. perenne.

The number of orthologous pairs for which $\mathrm{Ka}$ and Ks could be calculated and was above 1 was equal to: 210 for F. pratensis and L. multiflorum (Additional file 7: Table S7), 177 for $F$. pratensis and $L$. $m$. westerwoldicum (Additional file 8: Table S8), 203 for $F$. pratensis and $L$. temulentum (Additional file 9: Table S9), 124 for F. pratensis and L. perenne (Additional file 10: Table S10). All of the pairs have been linked to their functional annotations. We have then categorized the transcript pairs that are under positive pressure in multiple comparisons, by checking how many Festuca identifiers are being shared between the pairwise comparisons (Figure 6). The majority of pairs have shown $\mathrm{Ka} / \mathrm{Ks}$ values over 1 in only a single pair-wise comparison. However, there were three pairs

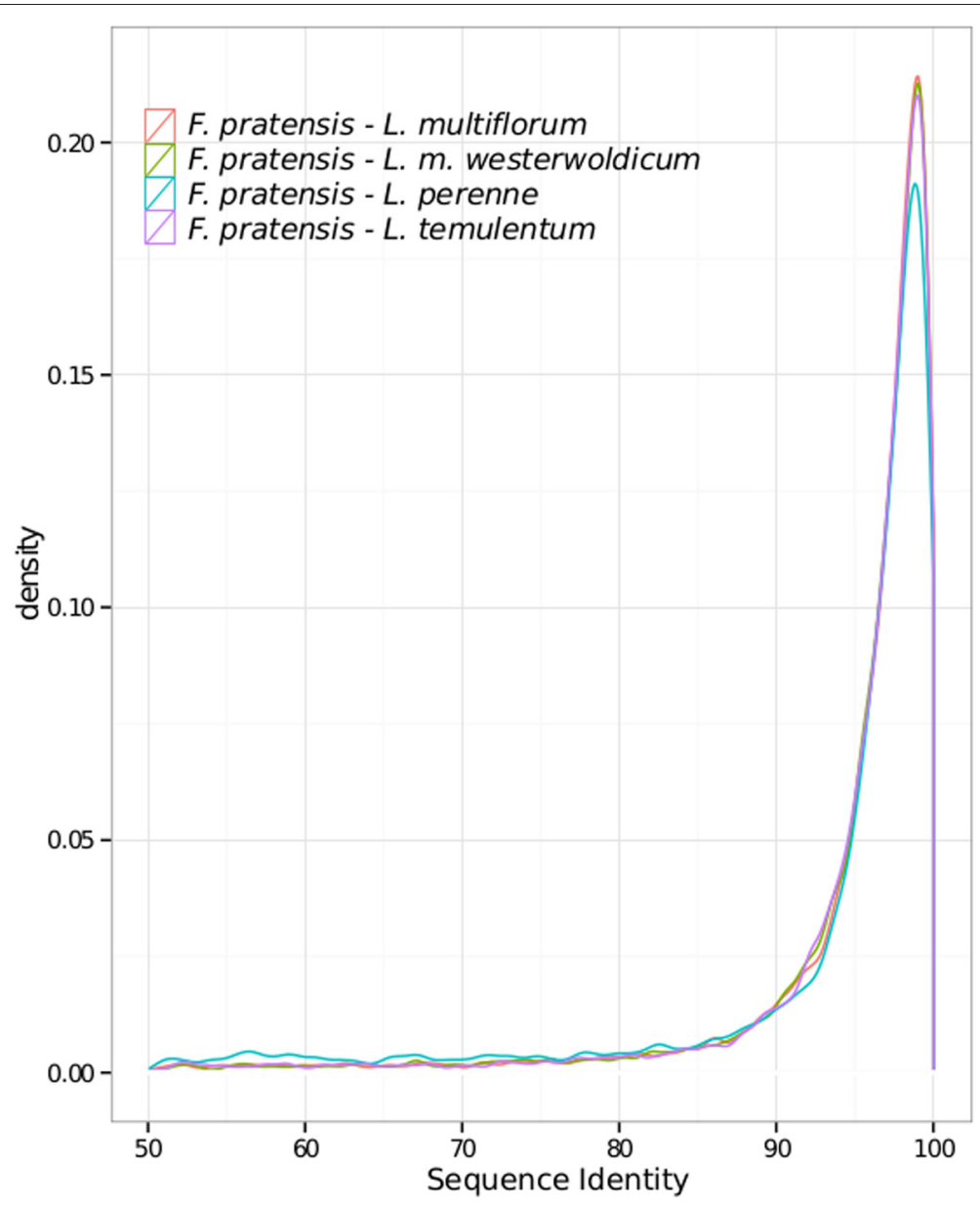

Figure 4 Sequence identity distribution of pairwise comparisons. The graph presents a distribution of protein identity between F. pratensis and the other Lolium-Festuca complex species used in pairwise BLAST comparisons. The kernel density plots are used here to view the distribution of a sequence identity. The $X$ axis represents sequence identity (Sqld) and the $Y$ axis shows kernel density. 
F. pratensis - L. multiflorum

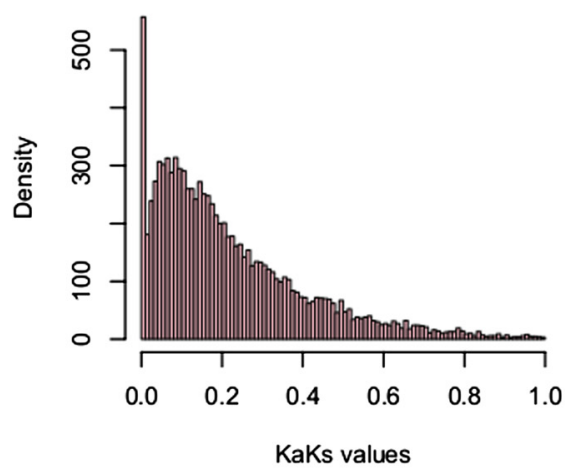

F. pratensis - L. perenne

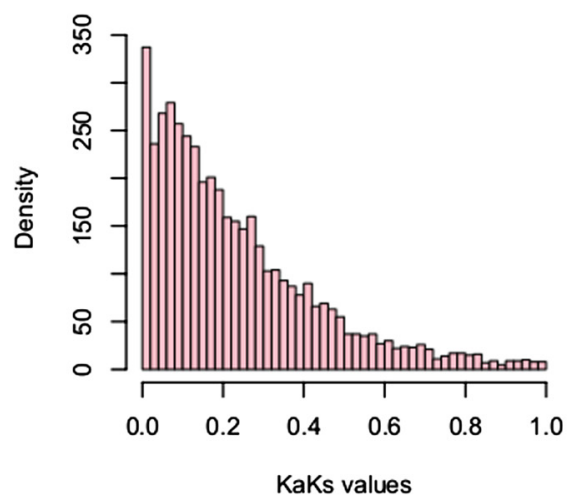

F. pratensis - L. m. westerwoldicum

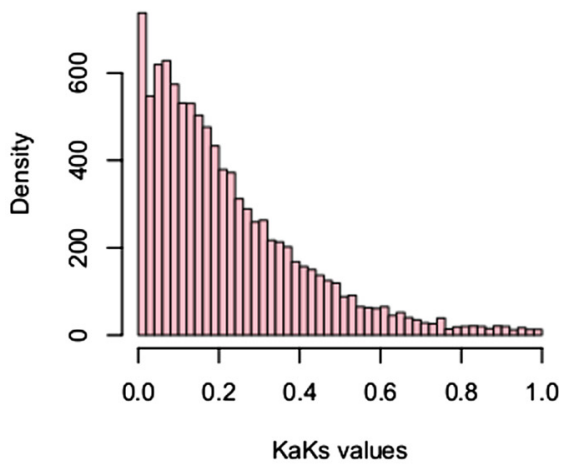

F. pratensis - L. temulentum

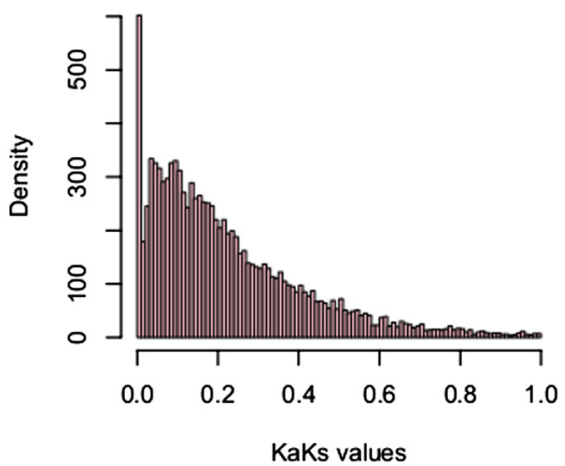

Figure $\mathbf{5} \mathrm{Ka} / \mathrm{Ks}$ distribution. The figure presents comparison of F. pratensis against L. temulentum, L.m. westerwoldicum, L. multiflorum and L. perenne. The frequency distributions of $\mathrm{Ka} / \mathrm{Ks}$ rates ( $\mathrm{x}$-axis) shown here are based on protein and nucleotide alignments of orthologous genes.

shared in every analyzed comparison, and thus differentiating the Festuca from the Lolium species. The first was a homologue of $A$. thaliana ribosomal protein L4, one of the primary rRNA binding proteins [62], and the second was a UNC93-like protein 2, which is an integral component of the cell membrane [63]. In addition, in every pairwise comparison we detected a homologue of disease resistance protein RPM1, involved in plant defense against $P$. syringae in A. thaliana [64]. A homologue to disease resistance protein RPP13 conferring resistance to Peronospora parasitica in A. thaliana [65] has been identified in L. perenne, L. multiflorum and L. temulentum comparisons. Other proteins involved in plant-pathogen interaction, RPP8 and RPH8A, have been found in the L. multiflorum comparison. Different types of F-box proteins, which are mediating protein-protein interactions, were also abundant in every pairwise comparison.

Because $F$. pratenesis and $L$. perenne are perennial plants, and L. multiflorum, L. m. westerwoldicum and $L$. temulentum have a bi-annual or annual growth cycle, protein types present in every type of comparison except for $F$. pratensis - L.perenne have been closely investigated. One example of such proteins are cyclins, family of conserved proteins responsible for the control of cell-cycle progression [66]. Cyclin T1-1, has been identified in all comparisons except for the comparison with L.perenne. Other cyclins, T1-4 and T1-5, and Cyclin-dependent kinase F4 have been identified in pairwise comparisons with $L$. temulentum E3 ubiquitin ligases have also been identified in every comparison apart from L.perenne - RNF128 in $L$. multiflorum, RFWD3 in L. m. westerwoldicum and RNF25 in L. temulentum. Additionally, multiple diverse transcription factors have been identified in non - L.perenne comparisons. These proteins constitute a group worth investigation of the perenniality/annuality trait genetic background.

When analyzing PFAM domains, the most abundant classes in every comparison were Leucine Rich Repeats, AAA domains and Tetratricopepdide repeats. All three of those protein domains can be found in proteins involved in diverse functions - such as protein-protein interactions, transcription factors, protein degradation 


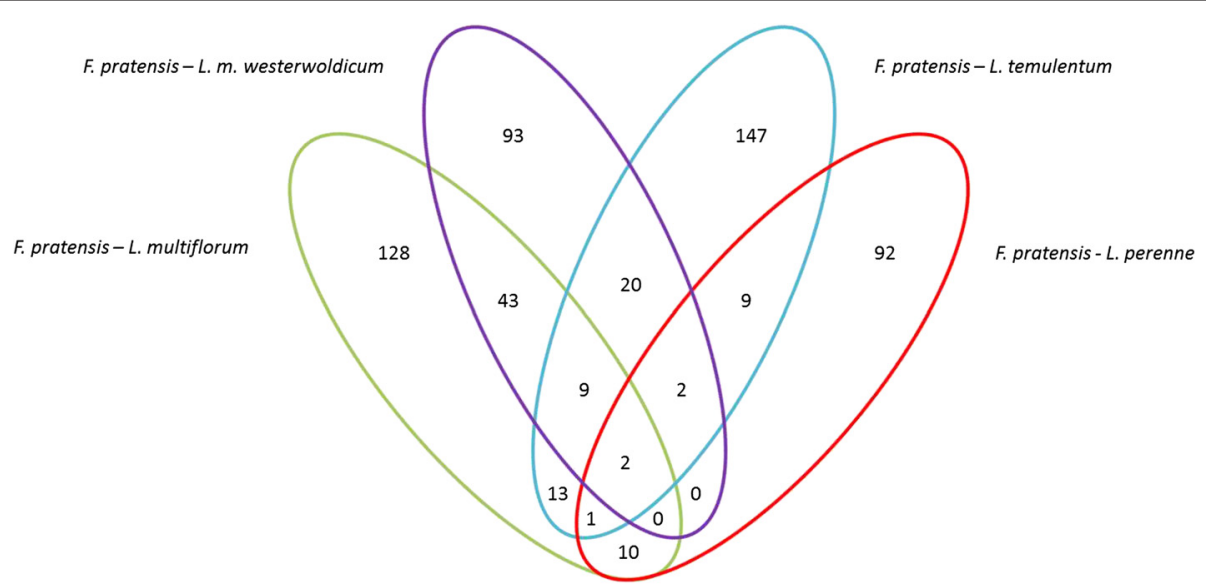

Figure 6 Organisation of proteins under positive selection in Festuca to Loliums comparison. The diagram show the number of proteins under positive selection between Festuca and analyzed Lolium species.

and signal transduction. The full list of annotated proteins and PFAM domains is available in Additional file 11.

Apart from the pairwise comparisons of Festuca to Lolium species, we have also performed a comparison of L. multiflorum and L. m. westerwoldicum, assuming that a large amount of changes on the molecular level might have been caused by human influence [37]. It is an interesting comparison as $L$. $m$. westerwoldicum was developed by selecting L. multiflorum plants for annuality. A very high number of positively selected orthologous pairs - 235 - has been identified for these two species (Additional file 12: Table S11). As the main difference between the species is the strictly annual habit of $L$. $m$. westerwoldicum, apart from the basic metabolism and disease resistance we were also interested in proteins related to development and perennialityannuality cycle. Annotations extracted from the previously created annotation files (Additional file 1: Table S1, Additional file 2: Table S2, Additional file 3: Table S3 and Additional file 4: Table S4) included multiple ubiquitin protein ligases as well as Cyclin-T1-1. Multiple disease resistance proteins have been identified: two RGA2 proteins, 1 RPM1 and one RPP13 protein. Among the pfam domain annotations we have found one that is related to seed dormancy control [PF14144.1], and two genes with a anaphase-promoting complex subunit [PF12861.2]. We have also identified multiple domains associated with sugar metabolism, such as fructose-1-6-bisphosphatase [PF00316.15], sugar efflux transporter for intercellular exchange [PF03083.11], MFS/sugar transport protein [PF13347.1] and sugar transporter [PF00083.19]. Another interesting category of domains included drought induced 19 protein (Di19) [PF05605.7] and Arabidopsis broadspectrum mildew resistance protein [PF05659.6]. In spite of the extremely close phylogenetic distance, the amount and diversity of proteins under putative positive selection between those two species is very high, likely reflecting the intense selection pressure applied during the breeding of L. m. westerwoldicum from L. multiflorum.

Many of the enriched terms identified as being positively selected in this study share functions comparable to the ones in similar analyses $[61,67,68]$. Terms associated with protein kinases, protein phospthatases, transcription regulation and glycotransferases are linked to disease resistance [67], which are one of the fastest evolving and critical proteins in plant evolution. Terms related to stress response were present in almost every comparison, which is not suprising given the phenotypic background of the plants. The VRN2 gene has been identified as being important for determining spring or winter wheat varieties [46]. We have often observed terms related to reproductive structure development. Seeds and fruit size are one of the most distinct differences between wild and domesticated plants. L. temulentum is considered to be a mimic weed of wheat, and as such it has been involuntarily domesticated alongside that species [69]. Breeding of perennial grasses has a much shorter history, with the earliest records of it starting around 90 years ago [70]. However, given the intensity of modern breeding programs and the fact that F. pratensis, L. multiflorum and L. $m$. westerwoldicum plants used in our study are a result of a directed breeding effort, it might be worth investigating if some of the observed variation could be related to domestication like processes.

\section{Conclusions}

This study presents the first de-novo transcriptome assemblies for four species from the Lolium-Festuca complex, and uses them to perform comparative transcritpomics. The orthologous genes between the species 
have a very high sequence similarities $(91,61 \%)$, and the majority of gene families were shared for all of them. A consensus phylogenetic tree based on our large set of oneto-one orthologous genes is in agreement with the most recent study that was based on nuclear ribosomal intergenic spacer and plastid trnT-L and trnL-F regions. It is likely that the knowledge of the genomes will be largely transferable between species within the complex.

\section{Methods}

\section{Sample collection}

In order to capture a broad sequence diversity, we have chosen four Lolium-Festuca species that differ highly between each other with regard to phenotypic traits. The seeds were obtained from the breeding company DLF-Trifolium, and three of the species were commercial breeding varieties; F. pratensis - "Laura", L.multiflorum "Lemtal", L. m. westerwoldicum "Nerissa". L. temulentum was a wild type. The seeds have been germinated and grown in the greenhouse under standard conditions. The RNA has been isolated on the 16th of April 2013 from mature leaf samples from single genotype of each of the four species using the RNeasy plant mini kit from Qiagen according to the manufacturers protocol.

\section{cDNA preparation and sequencing}

cDNA library preparation has been done using the TruSeq kit, generating paired-end libraries with insert size of $300 \mathrm{bp}$. Sequencing has been carried out by the Beijing Genomics Institute, using Illumina Hi-Seq platform (91 bp paired-end sequencing), as well as the Ion Proton platform for a subset (25,5 milion reads) of $L$. temulentum sequences (91 bp single-end sequencing). The adapters were removed and reads were quality trimmed by BGI.

\section{Error correction}

The original reads have been corrected for sequencing errors using the Allpaths-LG software (version 44837) built-in error correction tool [71], with default parameters. The tool is based on an algorithm eliminating exceptions from an overwhelming consensus read stack [30]. This process has reduced the total amount of paired-end reads by between 92.4 and $94.8 \%$.

\section{Assembly}

The samples from Illimuna and Ion Proton platforms have been merged and used together in the assembly. Trinity software [31] (version r2013_08_14) has been used for the generation of independent de-novo transcriptome assemblies, using the following parameters: -JM 20G min_contig_ 200 -full_cleanup -min_kmer_cov 2. This has resulted a total number of 96,710 assembled transcripts for F. pratensis, 69,651 for L.multiflorum, 63,112 for L. m. westerwoldicum and 76,751 for L. temulentum. The reads have been mapped back to their assembly using RSEM (version 2013-02-16) [72] in order to filter out transcripts with low support.

\section{Protein prediction}

Transdecoder (version r2013_08_14) [31] has been used to de novo predict putative coding regions and protein sequences using filtered transcripts as input. 39,981 proteins were predicted for F. pratensis, 30,940 for L. multiflorum, 30,182 for L. m. westerwoldicum and 35,005 for $L$. temulentum. CEGMA [73] pipeline was used to assess the completion of the transcriptome assemblies.

\section{Annotation}

The trinotate (release 2014.07.08) [31] pipeline was used for the annotation of the protein dataset. Both transcripts and proteins have been aligned using blast software [74] (version 2.2.28+), blastx and blastp respectively, using swissprot protein database (release 09_07_2014) as the target. HMMER [75] (version 3.1b1) with Pfam-A database [76] (version 27.0) has been used to identify protein domains, signalP [77] (version 4.1) was used to predict signal peptides and tmHMM [78] (version 2.0c) was used to predict transmembrane helices. The resulting information has been loaded into SQLite database and wrapped up by the Trinotate report script, creating a comprehensive annotation.

\section{Validation of assembly completion by CEGMA}

CEGMA software [73] (version 2.4.010312) has been used to assess the completion of the transcript dataset. The software was run with default parameters with the included reference dataset.

\section{Full-length transcript analysis}

We have used high confidence protein datasets from $T$. aestivum, $B$. distachyon and O. sativa, downloaded from MIPS PlantsDB database (30.07.2014) [79]. NCBI blastx was used (-evalue 1e-20 -max_target_seqs 1 -outfmt 6) to align each of our four filtered transcriptome assemblies to each of the protein databases separately. Afterwards we have used the analyze_blastPlus_topHit_coverage.pl script from the Trinity package to identify unique top matching proteins that align across certain length thresholds of the template sequence.

\section{Orthologous group assignment}

Predicted protein sequences have been clustered into orthologous groups using the OrthoMCL software [36]. The input protein dataset predicted by transdecoder has been filtered to contain only the proteins predicted from the longest, unique transcript splice variants, giving $19,863,17,718,18,095$, and 19,817 proteins, respectively. 
A custom perl script was used in order to get information about the number of clusters shared. A set of custom python scripts has been used to get information about groups with over- and underrepresented sequences and assesing a group wide pfam domain classification. Sequences from the species-unique groups have been aligned online with the NCBI protein database for manual functional annotation. Sequences having \%id hits below 40 have been discarded. Sequences having hits to putative or predicted proteins without any assigned function have not been considered for further analysis.

\section{Identification of putative orthologs}

For the identification of putative orthologs between two species, we applied bi-directional blastp [80] where two sequences are considered as orthologous if they satisfy a sequence identity cut-off over the length of amino acids $>30$ [81]. We have used the $F$. pratensis protein dataset predicted earlier for the identification of proteins under positive selection.

\section{Estimation of synonymous and non-synonymous substitution rate}

Orthologous gene pairs were aligned using CLUSTALW [82]. The maximum likelihood estimation of synonymous (Ks) and non-synonymous (Ka) substitution rate was estimated using the yn00 module of the PAML4 suite [83].

\section{Analysis of evolutionary conserved and relaxed groups}

For every sequence pair showing a $\mathrm{Ka} / \mathrm{Ks}$ ratio higher than 1 and below 10, a representative sequence was chosen. It was belonging to the $F$. pratensis for all but one case. $L$. multiflorum representative was chosen for the L. multiflorum and L. m. westerwoldicum pair. The choice of one of the two representatives did not change the final outcome of the analysis. Matching uniprot identifiers have been identified by aligning the representative sequences with $A$. thaliana uniprot sequences (accessed 16.09.2014). The results have been filtered to contain only hits to plant species. The uniprot identifiers have then been used af input for DAVID. Clustering was done using the default parameters, with the KEGG pathway, INTERPRO domain and Biological Process GO terms used for annotation and A. thaliana sequences as a background for enrichment study.

\section{Phylogenetic analysis}

OrthoMCL clusters have been filtered in search of clusters containing a single representative from each species. 4022 groups have been selected and used to infer gene trees using PAML4 suite [83]. The resulting trees have been which were then clustered using the consensus tree program, version 3.69 of the Phylip package [84] to infer a consensus tree.

\section{Availability of supporting data}

The error corrected transcriptome reads have been deposited in the SRA database under the following accession numbers: SRR1648382 (F.pratensis), SRR1648406 (L. multiflorum), SRR1648407 (L.m. westerwoldicum), SRR1648408, SRR1648409 and SRR1648494 (L. temulentum). The Transcriptome Shotgun Assembly project has been deposited at DDBJ/EMBL/GenBank under the accession numbers GBXZ00000000 (F.pratensis), GBXX00000000 (L. multiflorum), GBXY00000000 (L.m. westerwoldicum), and GBXW00000000 (L. temulentum). The versions described in this paper are the first versions, GBXZ01000000, GBXX01000000, GBXY01000000, and GBXW01000000 respectively.

\section{Additional files}

Additional file 1: Table S1. Trinotate annotation report for F. pratensis. Additional file 2: Table S2. Trinotate annotation report for $L$. multiflorum. Additional file 3: Table S3. Trinotate annotation report for L.m. westerwoldicum

Additional file 4: Table S4. Trinotate annotation report for $L$. temulentum. Additional file 5: Table S5. Biological Process Annotation of 100\% id groups.

Additional file 6: Table S6. GO Biological Process Annotation of $>80 \%$ id groups.

Additional file 7: Table S7. Annotations of proteins under putative positive selection in pairwise comparisons: F. pratensis - L. multiflorum Additional file 8: Table S8. Annotations of proteins under putative positive selection in pairwise comparisons: F. pratensis - L.m. westerwoldicum

Additional file 9: Table S9. Annotations of proteins under putative positive selection in pairwise comparisons: F. pratensis - L.temulentum. Additional file 10: Table S10. Annotations of proteins under putative positive selection in pairwise comparisons: F. pratensis - L.perenne.

Additional file 11: Number of orthologous protein pairs identified in H.vulgare vs Lolium-Festuca complex species using a range of \%identity thresholds.

Additional file 12: Table S11. Annotations of proteins under putative positive selection in pairwise comparisons: L. multiflorum - L.m. westerwoldicum.

\section{Competing interests}

The authors declare that they have no competing interests.

Authors' contributions

$A C, S B$, and TA concieved the study and participated in its design and coordination. AC performed the data analysis with contributions from SS, SB, MS, KFXM, and TA. AC wrote the final manuscript with contributions from SS, $\mathrm{SB}, \mathrm{MS}, \mathrm{KFXM}$, and TA. All authors read and approved the final manuscript.

\section{Acknowledgements}

We would like to thank Mr. Stephan Hentrup for his excellent technical support. This project was financed by the GUDP (Grønt Udviklings- og Demonstrationsprogram - Green Development and Demonstration Program) (3405-11-0241). 


\section{Author details}

${ }^{1}$ Department of Molecular Biology and Genetics, Aarhus University, Forsøgsvej 1, 4200 Slagelse, Denmark. ${ }^{2}$ Plant Genome and Systems Biology, Helmholtz Zentrum München, German Research Center for Environmental Health, Ingolstädter Landstrasse 1, 85764 Neuherberg, Germany.

Received: 2 December 2014 Accepted: 6 March 2015

\section{Published online: 28 March 2015}

\section{References}

1. Strickler SR, Bombarely A, Mueller LA. Designing a transcriptome next-generation sequencing project for a nonmodel plant species. Am J Bot. 2012:99(2):257-66.

2. Thomas H, Humphreys MO. Progress and potential of interspecific hybrids of lolium and festuca. J Agr Sci. 1991;117:1-8.

3. Xu WW, Sleper DA, Chao S. Detection of rflps in perennial ryegrass, using heterologous probes from tall fescue. Crop Sci. 1992;32(6):1366-70.

4. Bulinska-Radomska Z, Lester RN. Intergeneric relationships oflolium, festuca, andvulpia (poaceae) and their phylogeny. Plant Systemat Evol. 1988;159(3-4):217-27.

5. Charmet $\mathrm{G}$, Ravel C, Balfourier F. Phylogenetic analysis in the festuca-lolium complex using molecular markers and its rdna. Theor Appl Genet. 1997;94(8):1038-46.

6. Club MB. Michigan botanist. Michigan Botanical Club. http://hdl.handle. net/2027/spo.0497763.0038.101

7. Hand ML, Cogan NO, Stewart AV, Forster JW. Evolutionary history of tall fescue morphotypes inferred from molecular phylogenetics of the Iolium-festuca species complex. BMC Evol Biol. 2010;10:303.

8. Charmet $\mathrm{G}$, Balfourier $\mathrm{F}$. Isozyme variation and species relationships in the genus lolium I (ryegrasses, graminaceae). Theor Appl Genet. 1994:87(6):641-9.

9. Loureiro J, Kopecky D, Castro S, Santos C, Silveira P. Flow cytometric and cytogenetic analyses of iberian peninsula festuca spp. Plant Systemat Evol. 2007;269(1-2):89-105.

10. Humphreys MW, Thomas H. Improved drought resistance in introgression lines derived from lolium-multiflorum $x$ festuca-arundinacea hybrids. Plant Breeding. 1993;111(2):155-61.

11. Akiyama Y, Kimura K, Yamada-Akiyama H, Kubota A, Takahara Y, Ueyama Y. Genomic characteristics of a diploid f-4 festulolium hybrid (Iolium multiflorum x festuca arundinacea). Genome. 2012;55(8):599-603.

12. Yamada T, Forster JW, Humphreys MW, Takamizo T. Genetics and molecular breeding in lolium/festuca grass species complex. Grassland Science. 2005;51(2):89-106.

13. Polok K, Vol. 1. Molecular evolution of the genus Lolium L. Olsztyn: Studio Poligrafii Komputerowej "SQL"; 2007, pp. 15-19.

14. Humphreys MO. Genetic improvement of forage crops - past, present and future. J Agr Sci. 2005;143:441-8.

15. Breese EL, Lewis EJ, Evans GM. Interspecies hybrids and polyploidy. Phil Trans Roy Soc Lond B Biol Sci. 1981;292(1062):487-97.

16. Breese EL, Lewis EJ. Breeding versatile hybrid grasses. Span. 1984; 27(1):21-3.

17. Humphreys M, Thomas HM, Harper J, Morgan G, James A, GhamariZare $A$, et al. Dissecting drought- and cold-tolerance traits in the lolium-festuca complex by introgression mapping. New Phytologist. 1997;137(1):55-60.

18. Adomako B, Thorogood D, Clifford BC. Plant reaction types to crown rust (Puccinia coronata corda) disease inoculations in meadow fescue ( $F$. pratensis..), perennial ryegrass (L. perenne I) and L. perenne I. introgression lines. Int Turfgrass Res J. 1997;8:823-31.

19. Oertel C, Matzk F. Introgression of crown rust resistance from festuca spp. into lolium multiflorum. Plant Breeding. 1999;s118(6):491-6.

20. Rines HW, Porter HL, Carson ML, Ochocki GE. Introgression of crown rust resistance from diploid oat avena strigosa into hexaploid cultivated oat a sativa by two methods: direct crosses and through an initial $2 x$ center dot 4x synthetic hexaploid. Euphytica. 2007;158(1-2):67-79.

21. Armstead IP, Harper JA, Turner LB, Skot L, King IP, Humphreys MO, et al. Introgression of crown rust (puccinia coronata) resistance from meadow fescue (festuca pratensis) into italian ryegrass (lolium multiflorum): genetic mapping and identification of associated molecular markers. Plant Pathol. 2006;55(1):62-7.

22. Kosmala A, Zwierzykowski Z, Gasior D, Rapacz M, Zwierzykowska E, Humphreys MW. Gish/fish mapping of genes for freezing tolerance transferred from festuca pratensis to lolium multiflorum. Heredity. 2006;96(3):243-51.

23. Kosmala A, Zwierzykowski Z, Zwierzykowska E, Rapacz M, Joks W, Humphreys M. Introgression mapping for genes of abiotic stress resistance in lolium multiflorum and festuca pratensis. Czech J Genet Plant Breed. 2003;39(Special issue):342-4.

24. Buell CR. Poaceae genomes: going from unattainable to becoming a model clade for comparative plant genomics. Plant Physiol. 2009; 149(1):111-6.

25. Vogel JP, Garvin DF, Mockler TC, Schmutz J, Rokhsar D, Bevan MW. Genome sequencing and analysis of the model grass brachypodium distachyon. Nature. 2010;463(7282):763-8.

26. Yu J, Hu S, Wang J, Wong GK-S, Li S, Liu B, et al. A draft sequence of the rice genome (oryza sativa I. ssp indica). Science. 2002;296(5565):79-92.

27. Mayer KFX, Waugh R, Brown JWS, Schulman A, Langridge P, Platzer M, et al. A physical, genetic and functional sequence assembly of the barley genome. Nature. 2012;491(7426):711

28. Farrell JD, Byrne $S$, Paina C, Asp T. De novo assembly of the perennial ryegrass transcriptome using an rna-seq strategy. PLoS One. 2014;9(8): e103567. http://journals.plos.org/plosone/article?id=10.1371/journal. pone.0103567.

29. Ruttink T, Sterck L, Rohde A, Bendixen C, Rouze P, Asp T, et al. Orthology guided assembly in highly heterozygous crops: creating a reference transcriptome to uncover genetic diversity in lolium perenne. Plant Biotechnol J. 2013;11(5):605-17.

30. Gnerre S, MacCallum I, Przybylski D, Ribeiro FJ, Burton JN, Walker BJ, et al. High-quality draft assemblies of mammalian genomes from massively parallel sequence data. Proc Natl Acad Sci U S A. 2011;108(4):1513-8.

31. Grabherr MG, Haas BJ, Yassour M, Levin JZ, Thompson DA, Amit I, et al. Full-length transcriptome assembly from rna-seq data without a reference genome. Nat Biotechnol. 2011;29(7):644-52.

32. Parra G, Bradnam K, Ning Z, Keane T, Korf I. Assessing the gene space in draft genomes. Nucleic Acids Res. 2009;37(1):289-97.

33. Nakasugi K, Crowhurst RN, Bally J, Wood CC, Hellens RP, Waterhouse PM. De novo transcriptome sequence assembly and analysis of rna silencing genes of nicotiana benthamiana. PLoS ONE. 2013;8(3):59534.

34. Faino $\mathrm{L}$, de Jonge $\mathrm{R}$, Thomma BP. The transcriptome of verticillium dahliae-infected nicotiana benthamiana determined by deep rna sequencing. Plant Signal Behav. 2012;7(9):1065-9.

35. Moreno-Hagelsieb G, Latimer K. Choosing blast options for better detection of orthologs as reciprocal best hits. Bioinformatics. 2008; 24(3):319-24.

36. Li L, Stoeckert Jr. CJ, Roos DS. Orthomcl: identification of ortholog groups for eukaryotic genomes. Genome Res. 2003;13(9):2178-89.

37. Haan HD. Origin of westerwolths ryegrass (lolium multiflorum westerwoldicum). Euphytica. 1955:4(1):206-10

38. Distelfeld A, Tranquilli G, Li CX, Yan LL, Dubcovsky J. Genetic and molecular characterization of the vrn2 loci in tetraploid wheat. Plant Physiol. 2009:149(1):245-57.

39. Andres $F$, Coupland $G$. The genetic basis of flowering responses to seasonal cues. Nat Rev Genet. 2012;13(9):627-39.

40. Higgins JA, Bailey PC, Laurie DA. Comparative genomics of flowering time pathways using brachypodium distachyon as a model for the temperate grasses. Plos One. 2010;5(4):e10065.

41. Ergon A, Hamland $\mathrm{H}$, Rognli OA. Differential expression of vrn1 and other mads-box genes in festuca pratensis selections with different vernalization requirements. Biologia Plantarum. 2013;57(2):245-54. 182UJ Times Cited:3 Cited References Count:39.

42. Aamlid TS, Heide OM, Boelt B. Primary and secondary induction requirements for flowering of contrasting european varieties of lolium perenne. Ann Bot. 2000;86(6):1087-95.

43. Paina C, Byrne SL, Domnisoru C, Asp T. Vernalization mediated changes in the lolium perenne transcriptome. PLoS One. 2014;9(9):107365.

44. Dennis ES, Peacock WJ. Vernalization in cereals. J Biol. 2009:8(6):57.

45. Chen A, Dubcovsky J. Wheat tilling mutants show that the vernalization gene vrn 1 down-regulates the flowering repressor vrn2 in leaves but is not essential for flowering. Plos Genet. 2012;8(12):

46. Yan LL, Loukoianov A, Blechl A, Tranquilli G, Ramakrishna W, SanMiguel $P$, et al. The wheat vrn2 gene is a flowering repressor down-regulated by vernalization. Science. 2004;303(5664):1640-4.

47. Huang DW, Sherman BT, Lempicki RA. Systematic and integrative analysis of large gene lists using david bioinformatics resources. Nat Protoc. 2009:4(1):44-57. 
48. Fulton TM, Van der Hoeven R, Eannetta NT, Tanksley SD. Identification, analysis, and utilization of conserved ortholog set markers for comparative genomics in higher plants. Plant Cell. 2002;14(7):1457-67.

49. De Lichtenberg U, Jensen TS, Brunak S, Bork P, Jensen LJ. Evolution of cell cycle control: Same molecular machines, different regulation. Cell Cycle. 2007;6(15):1819-25. doi10.4161/cc.6.15.4537. http://dx.doi.org/10. 4161/cc.6.15.4537.

50. Pasakinskiene I, Anamthawat-Jonsson K, Humphreys MW, Paplauskiene $\mathrm{V}$, Jones RN. New molecular evidence on genome relationships and chromosome identification in fescue (festuca) and ryegrass (lolium). Heredity. 1998;81:659-65.

51. Catalan P, Torrecilla P, Lopez Rodriguez JA, Olmstead RG. Phylogeny of the festucoid grasses of subtribe loliinae and allies (poeae, pooideae) inferred from its and trnl-f sequences. Mol Phylogenet Evol. 2004; 31(2):517-41.

52. Darbyshire SJ. Realignment of festuca subgenus schedonorus with the genus lolium (poaceae). Novon. 1993;3(3):239-43.

53. Stammers M, Harris J, Evans GM, Hayward MD, Forster JW. Use of random pcr (rapd) technology to analyse phylogenetic relationships in the lolium/festuca complex. Heredity (Edinb). 1995;74(Pt 1):19-27.

54. Inda LA, Sanmartín I, Buerki S, Catalán P. Mediterranean origin and Miocene-Holocene Old World diversification of meadow fescues and ryegrasses (Festuca subgenus Schedonorus and Lolium). J Biogeogr. 2014:41:600-14

55. Humphreys M, Thomas HM, Harper J, Morgan G, James A, Ghamari-Zare A, et al. Dissecting drought- and cold-tolerance traits in the Lolium-Festuca complex by introgression mapping. New Phytologist. 1997;137:55-60.

56. King J, Armstead IP, Donnison SI, Roberts LA, Harper JA, Skot K, et al. Comparative analyses between lolium/festuca introgression lines and rice reveal the major fraction of functionally annotated gene models is located in recombination-poor/very recombination-poor regions of the genome. Genetics. 2007;177(1):597-606.

57. Harper J, Armstead I, Thomas A, James C, Gasior D, Bisaga M, et al. Alien introgression in the grasses Lolium perenne (perennial ryegrass) and Festuca pratensis (meadow fescue): the development of seven monosomic substitution lines and their molecular and cytological characterization. Ann Bot. 2011;107(8):1313-21.

58. Gaut BS, Tredway LP, Kubik C, Gaut RL, Meyer W. Phylogenetic relationships and genetic diversity among members of the Festuca-Lolium complex (Poaceae) based on ITS sequence data. Plant Syst Evol. 2000;224(1-2):33-55.

59. Yang ZH, Bielawski JP. Statistical methods for detecting molecular adaptation. Trends Ecol Evol. 2000;15(12):496-503.

60. Hurst LD. The ka/ks ratio: diagnosing the form of sequence evolution. Trends Genet. 2002;18(9):486-7.

61. Gross BL, Olsen KM. Genetic perspectives on crop domestication. Trends Plant Sci. 2010;15(9):529-37.

62. Trifa Y, Privat I, Gagnon J, Baeza L, Lerbs-Mache S. The nuclear rpl4 gene encodes a chloroplast protein that co-purifies with the t7-like transcription complex as well as plastid ribosomes. J Biol Chem. 1998;273(7):3980-5.

63. Theologis A, Ecker JR, Palm CJ, Federspiel NA, Kaul S, White O, et al. Sequence and analysis of chromosome 1 of the plant arabidopsis thaliana. Nature. 2000;408(6814):816-20.

64. Grant MR, Godiard L, Straube E, Ashfield T, Lewald J, Sattler A, et al. Structure of the arabidopsis rpm 1 gene enabling dual-specificity disease resistance. Science. 1995;269(5225):843-6.

65. Bittner-Eddy PD, Crute IR, Holub EB, Beynon JL. Rpp13 is a simple locus in arabidopsis thaliana for alleles that specify downy mildew resistance to different avirulence determinants in peronospora parasitica. Plant J. 2000;21(2):177-188.

66. John PCL, Mews M, Moore R. Cyclin/cdk complexes: their involvement in cell cycle progression and mitotic division. Protoplasma. 2001; 216(3-4):119-42.

67. Buschiazzo E, Ritland C, Bohlmann J, Ritland K. Slow but not low: genomic comparisons reveal slower evolutionary rate and higher $\mathrm{dn} / \mathrm{ds}$ in conifers compared to angiosperms. BMC Evol Biol. 2012;12:8.

68. Roth C, Liberles DA. A systematic search for positive selection in higher plants (embryophytes). BMC Plant Biol. 2006;6:12. http://www. biomedcentral.com/1471-2229/6/12.
69. Senda T, Tominaga T. Genetic diversity of darnel (lolium temulentum I.) in malo, ethiopia depends on traditional farming systems. Econ Bot. 2004;58(4):568-77.

70. Wilkins PW. Breeding perennial ryegrass for agriculture. Euphytica. 1991;52(3):201-14.

71. Maccallum I, Przybylski D, Gnerre S, Burton J, Shlyakhter I, Gnirke A et al. Allpaths 2: small genomes assembled accurately and with high continuity from short paired reads. Genome Biol. 2009;10(10):103.

72. Li B, Dewey CN. Rsem: accurate transcript quantification from rna-seq data with or without a reference genome. Bmc Bioinformatics. 2011; 12:323. http://www.biomedcentral.com/1471-2105/12/323.

73. Parra G, Bradnam K, Korf I. Cegma: a pipeline to accurately annotate core genes in eukaryotic genornes. Bioinformatics. 2007;23(9):1061-7.

74. Altschul SF, Gish W, Miller W, Myers EW, Lipman DJ. Basic local alignment search tool. J Mol Biol. 1990;215(3):403-10.

75. Finn RD, Clements J, Eddy SR. Hmmer web server: interactive sequence similarity searching. Nucleic Acids Res. 2011;39:29-37.

76. Finn RD, Bateman A, Clements J, Coggill P, Eberhardt RY, Eddy SR, et al. Pfam: the protein families database. Nucleic Acids Res. 2014 42(D1):222-30.

77. Petersen TN, Brunak S, von Heijne G, Nielsen H. Signalp 4.0: discriminating signal peptides from transmembrane regions. Nat Methods. 2011;8(10):785-6.

78. Krogh A, Larsson B, von Heijne G, Sonnhammer ELL. Predicting transmembrane protein topology with a hidden markov model: Application to complete genomes. J Mol Biol. 2001;305(3):567-80.

79. Nussbaumer T, Martis MM, Roessner SK, Pfeifer M, Bader KC, Sharma S, et al. Mips plantsdb: a database framework for comparative plant genome research. Nucleic Acids Res. 2013;41(D1):1144-51.

80. Altschul SF, Madden TL, Schaffer AA, Zhang JH, Zhang Z, Miller W, et al. Gapped blast and psi-blast: a new generation of protein database search programs. Nucleic Acids Res. 1997;25(17):3389-402.

81. Hu T,, Pattyn P, Bakker EG, Cao J, Cheng JF, Clark RM, et al. The arabidopsis lyrata genome sequence and the basis of rapid genome size change. Nature Genet. 2011;43(5):476.

82. Larkin M, Blackshields G, Brown N, Chenna R, McGettigan P, McWilliam $\mathrm{H}$, et al. ClustalW and ClustalX version 2. Bioinformatics. 2007;23:2947-8.

83. Yang ZH. Paml 4: Phylogenetic analysis by maximum likelihood. Mol Biol Evol. 2007;24(8):1586-91.

84. Felsenstein J. Phylip: phylogeny inference package (version 3.2) Cladistics. 1989:5:164-6.

\section{Submit your next manuscript to BioMed Central and take full advantage of:}

- Convenient online submission

- Thorough peer review

- No space constraints or color figure charges

- Immediate publication on acceptance

- Inclusion in PubMed, CAS, Scopus and Google Scholar

- Research which is freely available for redistribution 